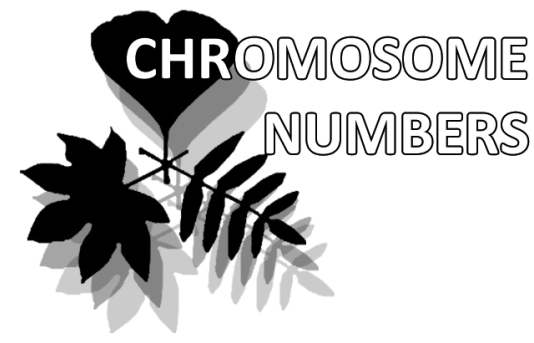

Nina S. Probatova ${ }^{1 *}$

e-mail: probatova@ibss.dvo.ru

Vyacheslav Yu. Barkalov ${ }^{1}$

e-mail: barkalov@ibss.dvo.ru

Nikolai V. Stepanov ${ }^{2}$

e-mail: stepanov-nik@mail.ru

${ }^{1}$ Federal Scientific Center of Biodiversity of the East Asian Terrestrial Biota FEB

RAS, Vladivostok, Russia

${ }^{2}$ Siberian Federal University, Krasnoyarsk, Russia

* corresponding author

Manuscript received: 24.05.2017

Review completed: 05.06.2017

Accepted for publication: 06.06.2017

Published online: 09.06.2017

\section{Chromosome numbers in some vascular plant species from Siberia and the Russian Far East}

\author{
Nina S. Probatova ${ }^{1 *}$, Vyacheslav Yu. Barkalov ${ }^{1}$ \& \\ Nikolai V. Stepanov ${ }^{2}$
}

\begin{abstract}
A B S T R A C T
Chromosome numbers $(\mathrm{CN})$ for 22 species of vascular plants from 17 genera (11 families): Crepis, Adenophora, Weigela, Arenaria, Psammophiliella, Hylotelephium, Phyllodoce, Phlomoides, Luqula, Agrostis, Elymus, Elytrigia, Eragrostis, Festuca (Schedonorus), Poa, Physaliastrum, Viola from Siberia and the Russian Far East are presented. For 9 species: Crepis coreana (Nakai) H.S. Pak (Asteraceae), Weigela suavis L.H. Bailey (Caprifoliaceae), Arenaria redowskii Cham. et Schltdl. (Caryophyllaceae), Hylotelephium pseudospectabile (Praeger) S.H. Fu (Crassulaceae), Phlomoides pacifica Kamelin et Schlotg. (Lamiaceae), Elytrigia amgunensis (Nevski) Nevski, Festuca gudoschnikovii Stepanov (Poaceae), Physaliastrum japonicum (Franch. et Sav.) Honda (Solanaceae) and Viola kusnezowiana W. Becker (Violaceae) the CN are revealed for the first time. The new CN were obtained for Adenophora curvidens Nakai, Luzula beringensis Tolm. and Eragrostis imberbis (Franch.) Prob. In the RFE Phyllodoce caerulea (L.) Bab. was studied first caryologically. Besides, the $\mathrm{CNs}$ were studied for the first time: in Khabarovskii krai - for Agrostis clavata Trin., A. stolonifera L., Elymus sibiricus L. and Poa angustifolia L.; in Primorskii Krai - for Elymus gmelinii (Trin.) Tzvelev and Psammophiliella muralis (L.) Ikonn.; in Kamchatka Peninsula for Echinocbloa crus-galli (L.) P. Beauv.; in Buryatia Republic - for Poa palustris L.

K e y w o r d s : chromosome numbers, vascular plants, flora, Siberia, Russian Far East
\end{abstract}

\section{P E 3 Ю M E}

Пробатова Н.С., Баркалов В.Ю., Степанов Н.В. Числа хромосом некоторых виАов сосуАистых растений из Сибири и АаАьнего Востока России. Сообщаются числа хромосом (2n) Аля 22 вилов сосудистых растений из 17 родов (11 семейств): Crepis, Adenophora, Weigela, Arenaria, Psammophiliella, Hylotelephium, Phyllodoce, Phlomoides, Luzula, Agrostis, Elymus, Elytrigia, Eragrostis, Festuca (Schedonorus), Poa, Physaliastrum, Viola во фморе Сибири и Аальнего Востока России. Впервые исследованы в кариологическом отношении Crepis coreana (Nakai) H.S. Pak (Asteraceae), Weigela suavis L.H. Bailey (Caprifoliaceae), Arenaria redowskii Cham. et Schltdl. (Caryophyllaceae), Hylotelephium pseudospectabile (Praeger) S.H. Fu (Crassulaceae), Pblomoides pacifica Kamelin et Schlotg. (Lamiaceae), Elytrigia amgunensis (Nevski) Nevski, Festuca gudoschnikovii Stepanov (Poaceae), Physaliastrum japonicum (Franch. et Sav.) Honda (Solanaceae) и Viola kusnezowiana W. Becker (Violaceae). А^я Adenophora curvidens Nakai, Luzula beringensis Tolm. и Eragrostis imberbis (Franch.) Prob. выявиены новые (не известные ранее) значения чисел хромосом. На P $\triangle$ B Phyllodoce caerulea (L.) Bab. впервые исследован в кариологическом отношении. Кроме того, впервые исслеАованы: в Хабаровском крае - Agrostis clavata Trin., A. stolonifera L., Elymus sibiricus L. и Poa angustifolia L.; в Приморском крае - Elymus gmelinii (Trin.) Tzvelev и Psammophiliella muralis (L.) Ikonn.; на п-ове Камчатка - Echinochloa crus-galli (L.) P. Beauv.; в Респуб̆ике Бурятия - Poapalustris L.

Кн очевые с м ов а: числа хромосом, сосудистые растения, флора, Сибирь, Аальний Восток России
We announce new results on chromosome number $(\mathrm{CN})$ study of 22 species of vascular plants from Siberia and the Russian Far East (RFE). (Fig. 1). This contribution continue previous publications as to Poaceae of Russia (Probatova et al. 2015, 2016, 2017), and these data on Poaceae will be added to the book "Grasses of Russia" by Tzvelev \& Probatova (in press). Chromosome countings in most species were made by E.G. Rudyka, in 2 species - by N.V. Stepanov, on squashed preparations of root tips. The root tips were taken and fixed with Carnoy's solution by N.S. Probatova from living plants, or from seedlings obtained through herbarium specimens, which were collected in the field. Preparations were stained with iron hematoxylin. Voucher specimens are mainly preserved in VLA, 2 vouchers - in KRSU. First $\mathrm{CN}$ data for the species are indicated by asterisk $(*)$. The number of the dot on the map follows the number of voucher specimen. Brief information about affinity and distribution of the species studied is given.

\section{ASTERACEAE}

*Crepis coreana (Nakai) H.S. Pak (Hieracium coreanum $\mathrm{Na}$ kai), $2 \mathrm{n}=16$

Russia, Far East, Khabarovskii Krai, Nanayskii Raion, Sikhote-Alin' mountain range, Tardoki-Yangi Mt., 1900 m 
alt., meadow in the Betula ermanii belt, 29 Aug 2012, coll. V.Yu. Barkalov 12193: 1 (VLA). Distribution: North-East China, Korean Peninsula. Mountain meadow species. In Russia it is found in Sikhote-Alin' mountain range, in the subalpine zone and in the Betula ermanii zone. Described from Korean Peninsula. The $\mathrm{CN}$ is studied for the first time. C. coreana was excluded, through misunderstanding, from earlier publication (Probatova et al. 2013), but it was not excluded there from Annotation with erroneous $\mathrm{CN}$, which is clarified now. $2 \mathrm{n}=4 \mathrm{x}$. The CN $2 \mathrm{n}=16$ is typical for the genus Crepis, but not for Hieracium.

\section{CAMPANULACEAE}

Adenophora curvidens $\mathrm{Nakai}$ (A. sublata Kom.), $* 2 \mathbf{n}=34$

Russia, Far East, Khabarovskii Krai, Verkhnebureinskii Raion, Badzhal'skii mountain range, at the mouth of Bugar River - right tributary of the Yarap River in its middle course, riverside rocks, among shrubs, 14 Aug 2016, coll. V.Yu. Barkalov 13106: 2 (VLA). East Siberia, Far East. Deciduous (Betula, Quercus), mixed and coniferous forests, up to subalpine zone. Described from North Korea. Very polymorphous species. We revealed a new, diploid $\mathrm{CN}$ for this species: before the tetraploid CN 2n = 68 was known, from Amurskaya Oblast' (Probatova \& Sokolovskaya 1989 - as A. sublata). $2 \mathrm{n}=2 \mathrm{x}, 4 \mathrm{x}$.

\section{CAPRIFOLIACEAE}

\section{*Weigela suavis L.H. Bailey, $2 \mathrm{n}=36$}

Russia, Far East, Khabarovskii Krai, Verkhnebureinskii Raion, Badzhal'skii mountain range, at the mouth of Bugar River - right tributary of the Yarap River in its middle course, valley forest, 14 Aug 2016, coll. V.Yu. Barkalov 13107: 2 (VLA). Area of distribution: north of the Amur River basin. Endemic. Described from Khabarovskii Krai (near Bolon'-Odzhal Lake). Rare, poorly studied species. Mountain forests (Picea ajanensis), in the zone of Pinus pumila, along streams and small rivers. The $\mathrm{CN}$ of the species is revealed for the first time. Two other species of Weigela in the RFE also have $2 \mathrm{n}=36$ (see Agapova et al. 1990). $2 \mathrm{n}$ $=4 \mathrm{x}$.

\section{CARYOPHYLLACEAE}

*Arenaria redowskii Cham. et Schltdl., $2 \mathrm{n}=22$

Russia, Far East, Khabarovskii Krai, Verkhnebureinskii Raion, Badzhal'skii mountain range, the middle course of the Yarap River, sandy-pebble sediments, 31 Jul 2016, coll. V.Yu. Barkalov 13037: 2 (VLA). Transbaikalia and the south part of the RFE. In subalpine zone, on mossy bogs, carbonate rocks, on pebbles along streams. Described from Khabarovskii Krai. Very polymorphous species. The CN of this species is studied for the first time. $2 \mathrm{n}=2 \mathrm{x}$.

\section{Psammophiliella muralis (L.) Ikonn., 2n = 34}

Russia, Far East, Primorskii Krai, Muravëv-Amurskii Peninsula, Vladivostok city, Akademgorodok, as a weed on the flower-bed, 15 Oct 2016, coll. N.S. Probatova and V.P. Seledets 13030: 3 (VLA). Euro-Mediterranean species, adventive in Siberia and in continental part in the south of the RFE. As a ruderal weed in settlements, along roadsides, in the fields. The first CN count in the Primorskii Krai. Be-

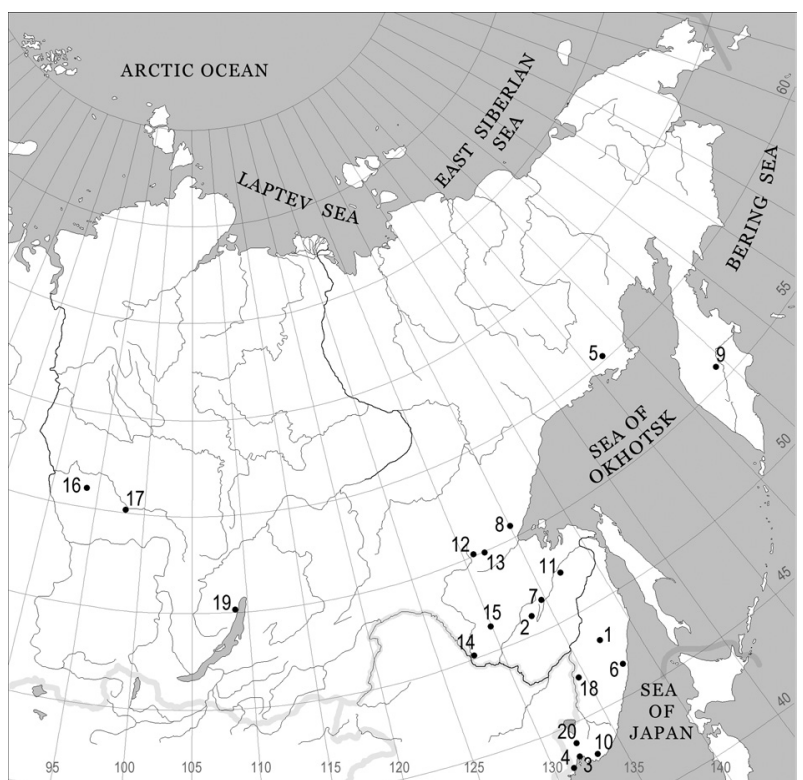

Figure 1 Study area. Dots with numbers from 1 to 20 are the sampling plot locations (according to numbering in the text)

fore the CN was studied from Amurskaya Oblast' (Probatova et al. 2005). $2 \mathrm{n}=2 \mathrm{x}$.

\section{CRASSULACEAE}

*Hylotelephium pseudospectabile (Praeger) S.H. Fu, 2n = 24

Russia, Far East, Primorskii Krai, Khassanskii Raion, Priozernaya Mt., on the rocks, among shrubs, 17 Jun 2014, coll. V.Yu. Barkalov 12667: 4 (VLA). Chinese-Korean rocky species; in Russia it occurs only in the south of Primorye (Goncharova 2006a, b). For the time being the Priozernaya Mt. is a unique locality of this species in Russia. The CN of H. psendospectabile is studied for the first time. $2 \mathrm{n}=4 \mathrm{x}$.

\section{ERICACEAE}

\section{Phyllodoce caerulea (L.) Bab., 2n = 24}

Russia, Far East, Khabarovskii Krai, Verkhnebureinskii Raion, Badzhal'skii mountain range, the middle course of Yarap River, the slope of the mountain $1500 \mathrm{~m}$, Betula ermanii forest, 30 Jul 2016, coll. V.Yu. Barkalov 13053: 2 (VLA). Holarctic. In almost all the RFE, except south part. Mountain tundras with low shrubs, mossy-lichen tundras, in alpine zone near snowfields. The $\mathrm{CN}$ is studied first in the RFE. $2 \mathrm{n}=4 \mathrm{x}$.

\section{JUNCACEAE}

\section{Luzula beringensis Tolm., $* 2 \mathrm{n}=24$}

Russia, Far East, Magadanskaya Oblast', Khassynskii Raion, Ol'skoe Plateau, Skif Mt. (1662 m), the watershed of the Ola and Maltan rivers, along the temporary reservoir, the big stones' slide-rocks on the slope, 8 Aug 2011, coll. V.Yu. Barkalov 12117: 5 (VLA). Chukotka, North Koryakia, Okhotia. Mountain tundras. The species was poorly studied. Its CN was known from Chukotka and North Koryakia: $2 \mathrm{n}=36$ (Zhukova 1967, Probatova \& Sokolovskaya 1983). This was, as we see, the hexaploid $\mathrm{CN}(6 \mathrm{x})$, and now we revealed the tetraploid $\mathrm{CN} 2 \mathrm{n}=24(\mathrm{x}=6)$. This species is studied in Magadanskaya Oblast' at the southern limit of 
its geographical distribution. $2 \mathrm{n}=4 \mathrm{x}, 6 \mathrm{x}$. Variable ploidy.

\section{LAMIACEAE}

*Phlomoides pacifica Kamelin et Schlotg., 2n = 24

Russia, Far East, Khabarovskii Krai, Sovgavanskii Raion, the Botchinskii nature reserve, the upper course of Mul'pa River (the tributary of Botchi River), the valley of Solontsovyi spring, Picea forest, 10 Aug 1999, coll. S.D. Shlotgauer \& M.V. Kriukova 8188: 6 (VLA). Earlier, this specimen was referred to P. alpina (Pall.) Adylov, Kamelin et Makhm. (Probatova et al. 2006). Almost at the same time P. pacifica was described from the Botchinskii nature reserve, by R.V. Kamelin and S.D. Schlotgauer (2006): these authors consider $P$. pacifica as more close to the other Far East species - P. woroschilovii (Makarov) Czerep., the endemic of Badzhal'skii mountain range, while $P$. alpina is mainly the Altai species. $2 \mathrm{n}=4 \mathrm{x} ; \mathrm{x}=6$.

\section{POACEAE}

\section{Agrostis clavata Trin., $2 \mathrm{n}=42$}

Russia, Far East, Khabarovskii Krai, Verkhnebureinskii Raion, Badzhal'skii mountain range, the valley of Yarap River, $12 \mathrm{~km}$ downstream from the confluence of Left Yarap and Right Yarap, along the old stony overgrown river-bed, 31 Jul 2016, coll. V.Yu. Barkalov 13050: 7 (VLA). Area of distribution: Europe (except south), Asia, North America (Alaska). Coniferous and mixed forests, among shrubs, forest glades, meadows, riverside sands and gravels; up to the middle mountain belt. Described from Kamchatka. The species was perfectly studied caryologically. Many CN counts from the Baikal Siberia and the RFE (for Poaceae the references will be done in the book "Grasses of Russia", mentioned above). This is the first CN count from Khabarovskii Krai. $2 \mathrm{n}=4 \mathrm{x}$.

\section{Agrostis stolonifera L., $2 \mathrm{n}=28$}

Russia, Far East, Khabarovskii Krai, Ayano-Mayskii Raion, Nel'kan settlement, Jul 2016, coll. M.I. Vernoslova 13105: 8 (VLA). Very polymorphous species. Eurasian, but as alien or introduced species - in many temperate regions. Described from Europe. Widely distributed in the RFE, but often as adventive plant. Meadows, swamps, riversides and lakesides, on sands and gravels, and as a weed, on roadsides, in settlements; up to the upper mountain belt. The $\mathrm{CN}$ was studied from Siberia, Primorskii Krai and the Kuriles. 2n = 4x (also aneuploids occur). In Khabarovskii Krai the $\mathrm{CN}$ in A. stolonifera is revealed for the first time.

\section{Echinochloa crus-galli (L.) P. Beauv., 2n = 54}

Russia, Far East, Kamchatskii Krai, Kamchatka Peninsula, Bystrinskii Raion, Anavgai village, 2015, coll. V.V. Buryi 13079: 9 (VLA). Almost cosmopolitan. In all the RFE, but in the north - near the thermal springs. Riversides, edges of swamps, often as a weed on plantations and roadsides. Described from "Europe and USA". In Kamchatka the CN for E. crus-galli is revealed for the first time. $2 \mathrm{n}=4 \mathrm{x}$ (rare), 6x (common); $\mathrm{x}=9$. Variable ploidy.

Elymus gmelinii Trin.) Tzvelev, $2 \mathrm{n}=28$

Russia, Far East, Primorskii Krai, Shkotovskii Raion, Petrovka settlement, coll. S.V. Prokopenko 13076: 10.
(VLA). Described from Altai. Distributed in Siberia, Far East, Central Asia. Widely distributed in the RFE, except Arctic, Commander Islands and the Kurils. Meadows, forest clearings, among shrubs; up to the middle mountain belt. Several CN counts from Siberia and RFE. In Primorskii Krai the $\mathrm{CN}$ of E. gmelinii is studied for the first time. $2 \mathrm{n}=4 \mathrm{x}$.

\section{Elymus sibiricus L., $2 \mathrm{n}=28$}

Russia, Far East, Khabarovskii Krai, Poliny Ossipenko Raion, Amghun' settlement, 2003, coll. L.A. Antonova 13111: 11. (VLA). Almost Holarctic. Described from Siberia. In all the RFE, except Arctic and the Kurile Islands. Clearings, forest edges, sands and gravels in the river valleys, on the slopes and screes, on roadsides; up to the middle mountain belt. From Khabarovskii Krai the CN for E. sibiricus is revealed for the first time. Multiple $\mathrm{CN}$ counts from Siberia and the RFE. $2 \mathrm{n}=4 \mathrm{x}$.

*Elytrigia amgunensis (Nevski) Nevski, 2n = 14

Russia, Far East, Khabarovskii Krai, Ayano-Mayskii Raion, left riverside of Maya River, opposite the mouth of Tommunzha River, on the scree, 29 Jul 2016, coll. M.I. Vernoslova 13102: 12 (VLA); Russia, Far East, Khabarovskii Krai, Ayano-Mayskii Raion, the Maya River basin, right riverside of Yakundzha River, pine forest, 28 Jul 2016, coll. M.I. Vernoslova 13104: 13 (VLA). Okhotia, Amgun', lower side of the Amur River basin. Endemic. Described from the Amgun' River basin (Chukchagirskoe Lake). Stony slopes, rocks, in lower and middle mountain belts. E. amgunensis belongs to E. aggr. strigosa (M. Bieb.) Nevski. Its closely related species in the RFE E. jacutorum (Nevski) Nevski is also endemic, with 2n = 14 (Zhukova \& Petrovsky 1977), but its area of distribution extends from Yakutia and Chukotka up to Sikhote-Alin' mountain range. First $\mathrm{CN}$ count for the species. $2 \mathrm{n}=2 \mathrm{x}$.

\section{Eragrostis imberbis (Franch.) Prob., $* 2 \mathrm{n}=20$}

Russia, Far East, Amurskaya Oblast', Blagoveshchensk city, roadside, 12 Sep 2001, coll. E. Aistova 11802: 14 (VLA); Russia, Far East, Amurskaya Oblast', $6 \mathrm{~km} \mathrm{NW}$ of Belogorsk town, the Tom' River, sandy sediments near the mouth of the former river-bed, SW of Tomskoe settlement, silty plots of sandbank along the riverside, 23-25 Aug 2006, coll. V.P. Verkholat 12087: 15 (VLA); Russia, Far East, Primorskii Krai, Vladivostok city, Postysheva Str., as a ruderal weed near the building, 22 Sep 2006, coll. N.S. Probatova \& V.P. Seledets 11912: 3 (VLA). Earlier the specimen № 11802 was erroneously referred to E. pilosa (L.) P. Beauv. (Probatova et al. 2016), but after the plants were revised by A.P. Seregin. Distribution of the species: East Siberia, Far East, Central Asia. Saline meadows, riverside sands and pebbles, roadsides. Described from the North-East of China. This is the new $\mathrm{CN}$ for E. imberbis: before only $2 \mathrm{n}$ $=40$ was known, from Amurskaya Oblast' (Probatova et al. 2009). $2 \mathrm{n}=2 \mathrm{x}, 4 \mathrm{x}$. Variable ploidy.

Festuca gigantea (L.) Vill., $2 \mathbf{n}=\mathbf{2 8}$ (N.V. Stepanov)

Russia, East Siberia, Krasnoyarskii Krai, Yermakovskii Raion, $5 \mathrm{~km}$ NE of Ossinovka village, the slope of a hill near the mouth of Bezym'annyi spring, (tributary of the Ossi- 
novka River), 4 Oct 2015, coll. N.V. Stepanov: 16 (KRSU). Actually, this species, as well as the next one, are considered to belong to a small genus Schedonorus P. Beauv. (Festuca sect. Schedonorus (P. Beauv.) W.D.J. Koch), with 5 species in Russia. However Schedonorus is not accepted unanimously up to now as a separate genus. The CN $2 n=28$ is unusual in F. gigantea (its common $\mathrm{CN}$ is $2 \mathrm{n}=42$; see Agapova et al. 1993), but $2 \mathrm{n}=28$ has been revealed already 3 times: from Novossibirskaya Oblast' (Salajirskii Kryazh), Krasnodarskii Krai (Abin River, the Kuban' River basin), Krasnoyarskii Krai (near Tanzybei). The polymorphism of this species deserves careful study. 2n $=4 \mathrm{x}, 6 \mathrm{x}$. Variable ploidy.

* Festuca gudoschnikovii Stepanov (F. gigantea var. arcana Stepanov), 2n = 28 (N.V. Stepanov)

Russia, East Siberia, Krasnoyarskii Krai, Yermakovskii Raion, in vicinity of Tanzybey settlement, the locality Vtoroe Kol'tso, the riverside of Malyi Kebezh River, Salix forest, 20 Aug 2016, coll. N. V. Stepanov: 17 (KRSU). Endemic of the Upper-Yenissey region. Rare species. In the valley mixed forests, at the edges of swamps. Described from Krasnoyarskii Krai. From closely related Festuca (Schedonorus) gigantea the species under discussion differs by panicles with erect branches adpressed to the axis, by spikelets larger 1.5-2 times, awns of lemmas shorter - up to $8 \mathrm{~mm}$ (aequal or subaequal to lemma); when maturing the spikelets become brownish irregularly and they look variegated. F. gudoschnikovii was discovered near the east limit of Schedonorus giganteus' area of distribution. First $\mathrm{CN}$ data for this species. $2 \mathrm{n}=4 \mathrm{x}$.

\section{Poa angustifolia L., 2n $=56$}

Russia, Far East, Khabarovskii Krai, Bikinskii Raion, outskirts of Bikin settlement, riverside of the Bikin River, Jul 2015, coll. M.V. Kriukova 12812: 18 (VLA). Eurasia, introduced to North America and elsewhere in the temperate regions. Dry meadows, steppes, riverside and coastal sands and pebbles, roadsides. In all the RFE (but alien in the north, in Sakhalin and in the Kurils). Described from Europe. In Russia the $\mathrm{CN}$ was studied from European part, the Baikal Siberia and RFE $(2 \mathrm{n}=56,63-64$, c. 70, 70-72), and this is the first $\mathrm{CN}$ report from Khabarovskii Krai. Variable ploidy. 2n $=8 \mathrm{x}, 9 \mathrm{x}, 10 \mathrm{x}$ and aneuploids.

Poa palustris L., $2 \mathrm{n}=28$

Russia, East Siberia, Republic of Buryatia, Severo-Baikal'skii Raion, Cape Kotel'nikovskii, $457 \mathrm{~m}$ alt., lakeside of the Baikal Lake, stony beach, 24 Sep 2016, coll. I.V. Yenuschenko 13057: 19 (VLA). Holarctic. In almost all the RFE. Wet and moist meadows, swampy places, clearings, among shrubs, riverside sands and gravels, roadsides; up to the middle mountain belt. Described from Europe. Very polymorphous species, one of the most common in Russia. Multiple CN counts in Russia, mainly from the RFE. This is the first $\mathrm{CN}$ report for P. palustris from Buryatia Republic. $2 \mathrm{n}=4 \mathrm{x}$.

\section{SOLANACEAE}

*Physaliastrum japonicum (Franch. et Sav.) Honda, 2n = 24 Russia, Far East, Primorskii Krai, Nadezhdinskii Raion, $10 \mathrm{~km} \mathrm{~W}$ from Razdol'noe settlement, clearing in the mixed forest, 21 Jun 2014, coll. V.A. Nechaev 12671: 20 (VLA). China, Japan. In Russia the representative of the small East Asian genus Physaliastrum occurs only in the south of the Primorskii Krai.Valley forests, clearings, among shrubs. Described from Japan. This is the first $\mathrm{CN}$ report for $P$. japonicum. The same $\mathrm{CN} 2 \mathrm{n}=24$ was revealed in the only one wild species of the closely related genus Physalis L. $-P$. franchetii Mast., from Primorskii Krai (see Probatova 2014). $2 \mathrm{n}=2 \mathrm{x}$

\section{VIOLACEAE}

\section{*Viola kusnezowiana W. Beck., 2n = 20}

Russia, Far East, Khabarovskii Krai, Verkhnebureinskii Raion, Badzhal'skii mountain range, the middle course of the Yarap River, riverside rocky outcrop, under forest canopy, 13 Aug 2016, coll. V.Yu. Barkalov 13006: 2 (VLA). The South Okhotia - North Sikhote-Alin' endemic species, which belongs to the monotypic section Memorabiles W. Becker. Described from the left side of the Amur River basin. In coniferous forests, on riverside rocks, in subalpine zone along the streams. The species was studied caryologically for the first time. $2 \mathrm{n}=4 \mathrm{x} ; \mathrm{x}=5$.

\section{CONCLUSION}

The 22 species from 17 genera (11 families) presented here show the diversity of CNs: different ploidy levels, a series of basic $\mathrm{CN}$ numbers ( $\mathrm{x}=4,5,6,7,9,10,11,12,17)$. The tetraploids $(4 \mathrm{x})$ prevail (11 species). There are species with variable ploidy in Adenophora, Echinochloa, Eragrostis, Festuca (Schedonorus), Luqula, Poa, and this phenomenon may indicate progressive species. The tetraploid CNs $(2 \mathrm{n}=4 \mathrm{x})$ reveal the optimal ploidy level for species. 9 species were studied caryologically for the first time. For 3 species the new $\mathrm{CN}$ were obtained.

\section{ACKNOWLEDGEMENTS}

The authors are grateful to E.G. Rudyka for participation in chromosome determinations and to plant collectors: L.A. Antonova, V.V. Buryi, M.V. Kriukova, V.A. Nechaev, S.V. Prokopenko, M.I. Vernoslova, I.V. Yenuschenko - for providing important herbarium material for our study.

\section{LITERATURE CITED}

Agapova, N.D., K.B. Arkharova, L.I. Vakhtina, E.A. Zemskova \& L.V. Tarvis 1990. Chromosome numbers in flowering plants of the flora of the USSR: Aceraceae-Menyanthaceae. Nauka, Leningrad, 509 pp. (in Russian). [Агапова H.A., Архарова К.Б., Вахтина А.И., Земскова Е.А., Тарвис А.В. 1990. Числа хромосом цветковых растений флоры СССР: семейства Aceraceae-Menyanthaceae. А.: Наука. 509 с.].

Agapova, N.D., K.B. Arkharova, L.I. Vakhtina, E.A. Zemskova \& L.V. Tarvis 1993. Chromosome numbers in flowering plants of the flora of the USSR: Moraceae-Zygophyllaceae. Nauka, St.-Petersburg, 430 pp. (in Russian). [Агапова H.А., Архарова К.Б., Вахтина А.И., Земскова Е.А., Тарвис А.В. 1993. Числа хромосом цветковых растений флоры CСCР: семейства Moraceae-Zygophyllaceae. СПб: Наука. 430 с.].

Goncharova, S.B. 2006a. Sedoideae (Crassulaceae) of the flora of the Russian Far East. Dal'nauka, Vladivostok, 223 pp. (in Russian). [Гончарова С.Б. 2006а. Очитковые (Sedoi- 
deae, Crassulaceae) фморы российского Аальнего Востока. ВАаАивосток: Аальнаука. 223 с.].

Goncharova, S.B. 2006b. Crassulaceae. Flora of the Russian Far East. In: Additions to the Vascular Plants of the Soviet Far East, vols. 1-8 (1985-1996) (A.E. Kozhevnikov \& N.S. Probatova, eds.), pp. 151-160, Dal'nauka, Vladivostok (in Russian) ГГончарова С.Б. 2006б. Толстянковые - Crassulaceae // ФАора российского Аальнего Востока. Аополнения и изменения к изданию "Сосудистые растения советского Аальнего Востока". Т. 1-8 (1985-1996) / под реА. А.Е. Кожевникова и Н.С. Пробатовой. ВАадивосток: Аальнаука. С. 151-160].

Kamelin, R.V. \& S.D. Schlotgauer. 2006. New species of the genus Phlomoides Moench (Lamiaceae) from the Far East of Russia. Novosti systematiki vysshikh rastenii 38: 202-204 (in Russian). [Камелин P.В., Шлотгауэр С.А. 2006. Новый вил рода Pblomoides Moench (Lamiaceae) с Аальнего Востока России // Новости систематики высших растений. 2006. Т. 38. С. 202-204].

Probatova, N.S. 2014. Chromosome numbers in vascular plants of the Primorskii Krai (Russian Far East). Dal'nauka, Vladivostok, 343 pp. (in Russian). [Пробатова H.C. 2014. Хромосомные числа сосудистых растений Приморского края (АаАьний Восток России). ВАаАивосток: АаАьнаука. 343 с.].

Probatova, N.S., V.Yu. Barkalov \& A.V. Agafonov 2017. Chromosome numbers in some Poaceae species from Russia. Uchenye rapiski Zabaikal'skogo gosuniversiteta, Biologicheskie Nauki 12(1):88-95. [Проб̆атова Н.С., Баркамов В.Ю., Агафонов А.В. 2017. Числа хромосом некоторых видов зцаков (Роасеае) флоры России // Ученые записки Забайкальского госуниверситета. Биологические науки. Т. 12, № 1. С. 88-95].

Probatova, N.S., S.G. Kazanovsky, V.Yu. Barkalov, E.G. Rudyka \& V.P. Seledets 2013. Chromosome numbers in vascular plants from diverse regions of Russia. Botanicheskii Zhurnal 98(2): 135-148 (in Russian). [Пробатова Н.С., Казановский С.Г., Баркалов В.Ю., Рудыка Э.Г., Селедец В.П. 2013. Числа хромосом сосудистых растений из разных регионов России // Ботанический журнац. 'Т. 98, № 2. С. 135-148].

Probatova, N.S., Z.V. Kozhevnikova, E.G. Rudyka, A.V. Shatokhina, A.E. Kozhevnikov, V.Yu. Barkalov \& V.P. Seledets 2009. Chromosome numbers in species of the flora of the Far East and East Siberia. Botanicheskii Zhurnal 94(5):764 780 (in Russian). [Пробатова Н.С., Кожевникова 3.В., Рудыка Э.Г., Шатохина А.В., Кожевников А.Е., Баркалов В.Ю., Селедец В.П. 2009. Числа хромосом виАов флоры Аальнего Востока и Восточной Сибири // Ботанический журнац. Т. 94, № 5. С. 764-780].
Probatova, N.S., E.G. Rudyka, V.Yu. Barkalov, I.A. Nesterova, S.G. Kudrin \& E.A. Chubar'. 2006. Chromosome numbers in vascular plants from the nature reserves of Primorskii Krai and Priamurye. Botanicheskii Zhurnal 91 (7):1117-1134 (in Russian). [Пробатова Н.С., Рудыка Э.Г., Баркалов В.Ю., Нестерова И.А., Кудрин С.Г., Чубарь Е.А. 2006. Числа хромосом сосудистых растений из заповедников Приморского края и Приамурья // Ботанический журнал. Т. 91, № 7. С. 1117-1134].

Probatova, N.S., V.P. Seledets \& V.Yu. Barkalov. 2015. Chromosome numbers in some species of Poaceae from Russia. Botanica Pacifica 4(1):59-67.

Probatova, N.S., V.P. Seledets \& O.A. Chernyagina. 2016. Chromosome numbers in some species of Poaceae from Russia: further studies. Botanica Pacifica 5(2):59-65.

Probatova, N.S., A.V. Shatokhina \& E.G. Rudyka 2005. Chromosome numbers in some species of dicots of the flora in Amurskaya Oblast'. Botanicheskii Zhurnal 90 (5): 779-792 (in Russian). [Пробатова Н.С., Шатохина А.В., Рудыка Э.Г. 2005. Числа хромосом некоторых АвуАольных флоры Амурской области // Ботанический журнал. Т. 90, № 5. С. 779-792.].

Probatova, N.S. \& A.P. Sokolovskaya 1983. Chromosome numbers in Adoxaceae, Chloranthaceae, Cupressaceae, Juncaceae, Poaceae. Botanicheskii Zhurnal 68(12):16831684 (in Russian). [Пробатова Н.С., Соколовская А.П. 1983. Числа хромосом [семейства Adoxaceae, Chloranthaceae, Cupressaceae, Juncaceae, Poaceae] // Ботанический журнал. Т. 68, № 12. С. 1683-1684].

Probatova, N.S. \& A.P. Sokolovskaya 1989. Chromosome numbers in vascular plants from Primorye, the Amur region, Sakhalin, Kamchatka and the Kuril Islands. Botanicheskii Zhurnal 74(1):120-123 (in Russian). [Пробатова Н.С., Соколовская А.П. 1989. Числа хромосом сосудистых растений из Приморья, Приамурья, Сахалина, Камчатки и Курильских островов / / Ботанический журнал. Т. 74, № 1. С. 120-123].

Zhukova, P.G. 1967. Chromosome numbers in some plant species from the Extreme North-East of the U.S.S.R. II. Botanicheskii Zhurnal 52(7):983-987 (in Russian). [Жукова П.Г. 1967. Числа хромосом у некоторых вилов растений Крайнего Северо-Востока СССР. II / / Ботанический журнал. Т. 52. № 7. С. 983-987].

Zhukova, P.G. \& V.V. Petrovsky 1977. Chromosome numbers in some plant species from West Chukotka. III Botanicheskii Zhurnal 62 (8): 1215-1223 (in Russian). [Жукова П.Г., Петровский В.В. 1977. Хромосомные числа некоторых видов растений Западной Чукотки. III // Ботанический журнал. Т. 62. № 8. С. 1215-1223]. 